\title{
Cellulophaga geojensis sp. nov., a member of the family Flavobacteriaceae isolated from marine sand
}

\author{
Correspondence \\ Jung-Hoon Yoon \\ jhyoon69@skku.edu
}

\author{
Sooyeon Park, ${ }^{1}$ Ki-Hoon Oh, ${ }^{1}$ Soo-Young Lee, ${ }^{1}$ Tae-Kwang Oh ${ }^{1}$ \\ and Jung-Hoon Yoon ${ }^{2}$
${ }^{1}$ Korea Research Institute of Bioscience and Biotechnology (KRIBB), PO Box 115, Yuseong, Daejeon, Republic of Korea Republic of Korea \\ ${ }^{2}$ Department of Food Science and Biotechnology, Sungkyunkwan University, Jangan-gu, Suwon,
}

\begin{abstract}
A Gram-stain-negative, aerobic, non-flagellated, non-spore-forming, motile (by gliding) bacterial strain, designated $\mathrm{M}-\mathrm{M}^{\top}{ }^{\top}$, was isolated from marine sand of Geoje island, Korea. Strain M-M6 ${ }^{\top}$ grew optimally at $25{ }^{\circ} \mathrm{C}$, at $\mathrm{pH} 7.0-8.0$ and in the presence of $2 \%(\mathrm{w} / \mathrm{v}) \mathrm{NaCl}$. Phylogenetic analyses based on $16 \mathrm{~S}$ rRNA gene sequences revealed that strain $\mathrm{M}-\mathrm{M} 6^{\top}$ fell within the clade comprising Cellulophaga species, forming a coherent cluster with Cellulophaga lytica ATCC $23178^{\top}$ and Cellulophaga fucicola NN015860 ${ }^{\top}$, with which it shared $16 \mathrm{~S}$ rRNA gene sequence similarities of 98.1 and $98.2 \%$, respectively. Sequence similarities between strain $\mathrm{M}-\mathrm{M} 6^{\top}$ and the type strains of other recognized Cellulophaga species were in the range 92.4-93.8\%. Strain MM6 ${ }^{\top}$ contained MK-6 as the predominant menaquinone and iso- $C_{15: 0}$, iso- $C_{15: 1} G$, iso- $C_{17: 0}$ 3$\mathrm{OH}$, and $\mathrm{C}_{16: 1} \omega 7 \mathrm{c}$ and/or iso- $\mathrm{C}_{15: 0} 2-\mathrm{OH}$ as the major fatty acids. The major polar lipids detected in strain $\mathrm{M}-\mathrm{M} 6^{\top}$ and the type strains of C. Iytica and C. fucicola were two unidentified lipids, one unidentified aminolipid and one unidentified aminophospholipid. The DNA G + C content of strain M-M6 ${ }^{\top}$ was 35.4 mol\%. Levels of DNA-DNA relatedness between strain M-M6 ${ }^{\top}$ and C. lytica JCM $8516^{\top}$ and C. fucicola JCM $21778^{\top}$ were 33 and $35 \%$, respectively.

Differential phenotypic properties and phylogenetic and genetic distinctiveness distinguished strain $\mathrm{M}-\mathrm{M} 6^{\top}$ from all recognized Cellulophaga species. On the basis of the data presented, strain $\mathrm{M}-\mathrm{M} 6^{\top}$ is considered to represent a novel species of the genus Cellulophaga, for which the name Cellulophaga geojensis sp. nov. is proposed. The type strain is ${\mathrm{M}-\mathrm{M} 6^{\top}}^{\top}\left(=\mathrm{KCTC}^{2} 3498^{\top}=\mathrm{CCUG}\right.$ $\left.60801^{\top}\right)$.
\end{abstract}

During screening of polysaccharide-degrading microorganisms from marine environments in the South Sea, Korea, many bacterial strains were isolated and characterized. One of these isolates, designated $\mathrm{M}-\mathrm{M} 6^{\mathrm{T}}$, which was isolated from marine sand, is described in this study. Comparative 16S rRNA gene sequence analysis showed that this novel strain is phylogenetically most closely related to members of the genus Cellulophaga. The genus Cellulophaga, a member of the family Flavobacteriaceae, phylum Bacteroidetes (Bernardet \& Nakagawa, 2006), was created by Johansen et al. (1999) with the reclassification of [Cytophaga] lytica (Lewin, 1969) as Cellulophaga lytica and the description of two novel species, Cellulophaga baltica and Cellulophaga fucicola. At the time of writing, the genus Cellulophaga comprised six recognized species,

Abbreviation: CMC, carboxymethylcellulose.

The GenBank/EMBL/DDBJ accession number of the $16 S$ rRNA gene sequence of strain $\mathrm{M}-\mathrm{MG}^{\top}$ is $\mathrm{HQ596527.}$

A supplementary figure is available with the online version of this paper.
C. lytica, C. baltica and C. fucicola (Johansen et al., 1999), Cellulophaga algicola (Bowman, 2000), Cellulophaga pacifica (Nedashkovskaya et al., 2004) and Cellulophaga tyrosinoxydans (Kahng et al., 2009). All members of the genus Cellulophaga have been isolated from marine habitats (Johansen et al., 1999; Bowman, 2000; Nedashkovskaya et al., 2004; Kahng et al., 2009). The aim of the present study was to determine the exact taxonomic position of strain $\mathrm{M}-\mathrm{M} 6^{\mathrm{T}}$ by using a polyphasic characterization.

Strain $\mathrm{M}-\mathrm{M} 6^{\mathrm{T}}$ was isolated by the dilution plating technique on marine agar 2216 (MA; Difco) at $25^{\circ} \mathrm{C}$ and was cultivated routinely on MA at $25{ }^{\circ} \mathrm{C}$. C. fucicola JCM $21778^{\mathrm{T}}$ and C. lytica JCM $8516^{\mathrm{T}}$, which were used as reference strains for DNA-DNA hybridization, fatty acid and polar lipid analyses, and a number of other phenotypic tests, were obtained from the Japan Collection of Microorganisms (JCM), Saitama, Japan. Cell morphology was examined by light microscopy (DP70; Olympus) and transmission electron microscopy (CM-20; Philips). The 
latter technique was also used to assess the presence of flagellation on cells from an exponentially growing MA culture. For this, cells were negatively stained with $1 \%$ $(\mathrm{w} / \mathrm{v})$ phosphotungstic acid and grids were examined after being air-dried. Gliding motility was investigated as described by Bowman (2000). The Gram reaction was determined by using the bioMérieux Gram stain kit according to the manufacturer's instructions. Growth under anaerobic conditions was determined after incubation in an anaerobic chamber (1029; Forma, $\mathrm{N}_{2} / \mathrm{CO}_{2} / \mathrm{H}_{2}$, $86: 7: 7 \%)$ on MA and on MA supplemented with potassium nitrate $(0.1 \%, w / v)$, both of which had been prepared anaerobically under a nitrogen atmosphere. Growth at 4, 15, 20, 25, 30, 37, 40 and $45{ }^{\circ} \mathrm{C}$ was measured on MA. Growth in the absence of $\mathrm{NaCl}$ and in the presence of $0.5,1.0,2.0$ and $3.0 \%(\mathrm{w} / \mathrm{v}) \mathrm{NaCl}$ was investigated in trypticase soy broth prepared according to the formula of the Difco medium except that $\mathrm{NaCl}$ was excluded and that $0.45 \%$ (w/v) $\mathrm{MgCl}_{2} \cdot 6 \mathrm{H}_{2} \mathrm{O}$ was added. Growth in the presence of $2.0-10.0 \%(\mathrm{w} / \mathrm{v}) \mathrm{NaCl}$ (final concentration, increments of $1.0 \%$ ) was measured in marine broth 2216 (MB; Difco). The $\mathrm{pH}$ range for growth was determined in $\mathrm{MB}$ adjusted to $\mathrm{pH} 4.5-9.5$ (increments of $0.5 \mathrm{pH}$ units) by using sodium acetate/acetic acid and $\mathrm{Na}_{2} \mathrm{CO}_{3} . \mathrm{pH}$ was verified after autoclaving. Catalase and oxidase activities were determined as described by Cowan \& Steel (1965). Hydrolysis of casein, hypoxanthine, xanthine, starch and Ltyrosine were performed on MA, by using the substrate concentrations described by Cowan \& Steel (1965). Nitrate reduction and hydrolysis of aesculin, gelatin, Tweens $(20$, 40, 60 and 80) and urea were investigated as described by Lányí (1987) with the modification that artificial seawater was used for preparation of media. Degradation of carboxymethylcellulose (CMC) and carrageenan was tested on basal medium agar [per litre artificial seawater: $12 \mathrm{~g}$ gellan gum, 1 g yeast extract, $0.5 \mathrm{~g} \mathrm{NH}_{4} \mathrm{Cl}, 50 \mathrm{ml} 1 \mathrm{M}$ Tris/ $\mathrm{HCl}(\mathrm{pH} 7.4)$ and $5 \mathrm{~g}$ low-melting-point agarose] containing $0.5 \%(\mathrm{w} / \mathrm{v})$ CMC (Sigma) and $l$-carrageenan (Sigma), respectively. Degradation activities of CMC and carrageenan were determined by flooding the agar surface with Congo red solution and $10 \times$ diluted Lugol's iodine solution, respectively. The artificial seawater contained (per litre distilled water) $23.6 \mathrm{~g} \mathrm{NaCl}, 0.64 \mathrm{~g} \mathrm{KCl}, 4.53 \mathrm{~g}$ $\mathrm{MgCl}_{2} \cdot 6 \mathrm{H}_{2} \mathrm{O}, 5.94 \mathrm{~g} \mathrm{MgSO}_{4} .7 \mathrm{H}_{2} \mathrm{O}$ and $1.3 \mathrm{~g} \mathrm{CaCl}_{2} \cdot 2 \mathrm{H}_{2} \mathrm{O}$ (Bruns et al., 2001). The presence of flexirubin-type pigments was investigated as described by Reichenbach (1992). Acid production from carbohydrates was determined according to Leifson (1963). Utilization of substrates as sole carbon and energy sources was tested as described by Baumann \& Baumann (1981), by using supplementation with $2 \%(\mathrm{v} / \mathrm{v})$ Hutner's mineral base (Cohen-Bazire et al., $1957)$ and $1 \%(\mathrm{v} / \mathrm{v})$ vitamin solution (Staley, 1968). $\mathrm{H}_{2} \mathrm{~S}$ production was tested as described by Bruns et al. (2001). Susceptibility to antibiotics was investigated on MA plates by using antibiotic discs (Advantec) containing the following ( $\mu \mathrm{g}$ per disc unless otherwise stated): ampicillin (10), carbenicillin (100), cephalothin (30), chloramphenicol (100), gentamicin (30), kanamycin (30), lincomycin (15), neomycin (30), novobiocin (5), oleandomycin (15), penicillin G (20 U), polymyxin B (100 U), streptomycin (50) and tetracycline (30). Enzyme activities and additional

Table 1. Differential phenotypic characteristics of strain $M-M 6^{\top}$ and the type strains of two phylogenetically related Cellulophaga species

Strains: 1, M-M6 ${ }^{\mathrm{T}}$; 2, C. lytica JCM $8516^{\mathrm{T}}$; 3, C. fucicola JCM $21778^{\mathrm{T}}$. Data are from this study unless otherwise indicated. All strains are positive for: gliding motility; activity of catalase and oxidase; hydrolysis of agar, aesculin, carrageenan, CMC, gelatin, starch, Ltyrosine and Tweens (20, 40, 60 and 80); utilization of cellobiose, Dgalactose, D-glucose, maltose, salicin and trehalose; acid production from cellobiose, D-galactose, D-glucose, lactose, maltose, D-mannitol, D-mannose, melibiose, trehalose and D-xylose; activity of alkaline phosphatase, esterase (C4), esterase lipase (C8), leucine arylamidase, valine arylamidase, acid phosphatase and naphthol-AS-BI-phosphohydrolase; and susceptibility to chloramphenicol, lincomycin and oleandomycin. All strains are negative for: Gram-staining; nitrate reduction; production of $\mathrm{H}_{2} \mathrm{~S}$; production of flexirubin-type pigments; hydrolysis of hypoxanthine, urea and xanthine; utilization of L-arabinose, acetate, benzoate, citrate, formate, L-malate, pyruvate and succinate; acid production from L-arabinose, melezitose, myoinositol, raffinose, L-rhamnose, D-ribose and D-sorbitol; activity of arginine dihydrolase, lysine decarboxylase, ornithine decarboxylase, lipase (C14), trypsin, $\alpha$-chymotrypsin, $\alpha$-galactosidase, $\beta$-glucuronidase and $\alpha$-fucosidase; and susceptibility to ampicillin, gentamicin, kanamycin, neomycin, penicillin $G$, polymyxin $B$, streptomycin and tetracycline.

\begin{tabular}{|c|c|c|c|}
\hline Characteristic & 1 & 2 & 3 \\
\hline Hydrolysis of casein & + & - & + \\
\hline \multicolumn{4}{|l|}{ Utilization of: } \\
\hline D-Fructose & + & - & - \\
\hline L-Glutamate & + & - & - \\
\hline D-Mannose & + & - & - \\
\hline Sucrose & + & - & - \\
\hline D-Xylose & + & - & - \\
\hline \multicolumn{4}{|l|}{ Acid production from: } \\
\hline D-Fructose & - & + & + \\
\hline Sucrose & + & + & - \\
\hline \multicolumn{4}{|l|}{ Enzyme activity (API ZYM) } \\
\hline Cystine arylamidase & + & + & - \\
\hline$\beta$-Galactosidase & + & + & - \\
\hline$\alpha$-Glucosidase & - & - & + \\
\hline$\beta$-Glucosidase & - & - & + \\
\hline$N$-Acetyl- $\beta$-glucosaminidase & + & - & + \\
\hline$\alpha$-Mannosidase & - & - & + \\
\hline \multicolumn{4}{|l|}{ Susceptibility to: } \\
\hline Carbenicillin & + & + & - \\
\hline Cephalothin & - & + & - \\
\hline Novobiocin & - & - & + \\
\hline DNA G $+\mathrm{C}$ content $(\mathrm{mol} \%)^{\star}$ & 35.4 & 33.0 & 32.4 \\
\hline
\end{tabular}

${ }^{\star}$ Data for the two reference strains taken from Reichenbach (1989) and Johansen et al. (1999). 
biochemical tests were performed by using the API ZYM and $20 \mathrm{E}$ systems (bioMérieux) with incubation at $25^{\circ} \mathrm{C}$ for $8 \mathrm{~h}$ and 3 days, respectively, according to the manufacturer's instructions. Morphological, cultural, physiological and biochemical characteristics of strain $\mathrm{M}-\mathrm{M}^{\mathrm{T}}$ are given in the species description below and in Table 1 .

Cell biomass of strain $\mathrm{M}-\mathrm{M} 6^{\mathrm{T}}$ for DNA extraction and for analyses of isoprenoid quinones and polar lipids was obtained from cultures grown for 3 days in $\mathrm{MB}$ at $25^{\circ} \mathrm{C}$. Chromosomal DNA was extracted and purified by the procedure described by Yoon et al. (1996), with the modification that RNase $\mathrm{T} 1$ was used in combination with RNase A to minimize contamination with RNA. The $16 \mathrm{~S}$ rRNA gene was amplified by PCR by using two universal primers as described previously (Yoon et al., 1998) and the PCR products were purified by using a QIAquick PCR purification kit (Qiagen). Sequencing of the amplified 16S rRNA gene and phylogenetic analysis were performed as described by Yoon et al. (2003). The almost-complete $16 \mathrm{~S}$ rRNA gene sequence of strain $\mathrm{M}-\mathrm{M} 6^{\mathrm{T}}$ determined in this study comprised $1441 \mathrm{nt}$, representing approximately $96 \%$ of the Escherichia coli 16S rRNA gene sequence. In the neighbour-joining phylogenetic tree based on $16 \mathrm{~S}$ rRNA gene sequences, strain $\mathrm{M}-\mathrm{M} 6^{\mathrm{T}}$ fell within the clade comprising Cellulophaga species, clustering coherently with the type strains of C. lytica and C. fucicola (Fig. 1). The relationships among strain $\mathrm{M}-\mathrm{M}^{\mathrm{T}}$, C. lytica ATCC $23178^{\mathrm{T}}$ and C. fucicola $\mathrm{NN} 015860^{\mathrm{T}}$ were also maintained in the trees constructed with the maximum-likelihood and maximum-parsimony algorithms (Fig. 1). Strain $\mathrm{M}-\mathrm{M}^{\mathrm{T}}$ exhibited 16S rRNA gene sequence similarity values of 98.1 and $98.2 \%$ to C. lytica ATCC $23178^{\mathrm{T}}$ and C. fucicola
NN015860 ${ }^{\mathrm{T}}$, respectively, and $92.4-93.8 \%$ to the type strains of other recognized Cellulophaga species.

Isoprenoid quinones were extracted as described by Komagata \& Suzuki (1987) and were analysed by using reversed-phase HPLC with a YMC ODS-A $(250 \times 4.6 \mathrm{~mm})$ column. The predominant isoprenoid quinone detected in strain $\mathrm{M}-\mathrm{M} 6^{\mathrm{T}}$ was menaquinone-6 (MK-6), which is in line with data for the genus Cellulophaga (Nedashkovskaya et al., 2004; Kahng et al., 2009) and all members of the family Flavobacteriaceae (Bernardet \& Nakagawa, 2006). For cellular fatty acid analysis, cell mass of strain $\mathrm{M}-\mathrm{M} 6^{\mathrm{T}}$, C. lytica JCM $8516^{\mathrm{T}}$ and C. fucicola JCM $21778^{\mathrm{T}}$ was harvested from MA plates after incubation for 3 days at $25{ }^{\circ} \mathrm{C}$. Fatty acids were saponified, methylated and extracted by using the standard MIDI protocol (Sherlock Microbial Identification System, version 4.0). The mixture of fatty acids was separated by GC (Hewlett Packard 6890) and components were identified by using the TSBA40 database of the Microbial Identification System (Sasser, 1990). The cellular fatty acid profile of strain $M-M 6^{T}$ is shown in Table 2, together with those of C. lytica JCM $8516^{\mathrm{T}}$ and C. fucicola JCM $21778^{\mathrm{T}}$. The major fatty acids $\left(>10 \%\right.$ of the total) found in strain $\mathrm{M}-\mathrm{M}^{\mathrm{T}}$ were iso$\mathrm{C}_{15: 0}$, iso- $\mathrm{C}_{15: 1} \mathrm{G}$, iso- $\mathrm{C}_{17: 0} 3-\mathrm{OH}$, and $\mathrm{C}_{16: 1} \omega 7 c$ and/or iso- $\mathrm{C}_{15: 0} 2-\mathrm{OH}$ (Table 2 ). The overall fatty acid profile of strain M-M6 ${ }^{\mathrm{T}}$ was similar to those of C. lytica JCM $8516^{\mathrm{T}}$ and C. fucicola JCM $21778^{\mathrm{T}}$, but the three strains could be differentiated based on differences in the respective proportions of some fatty acids (Table 2). Polar lipids were extracted according to the procedures described by Minnikin et al. (1984) and were identified by two-dimensional TLC followed by spraying with molybdophosphoric

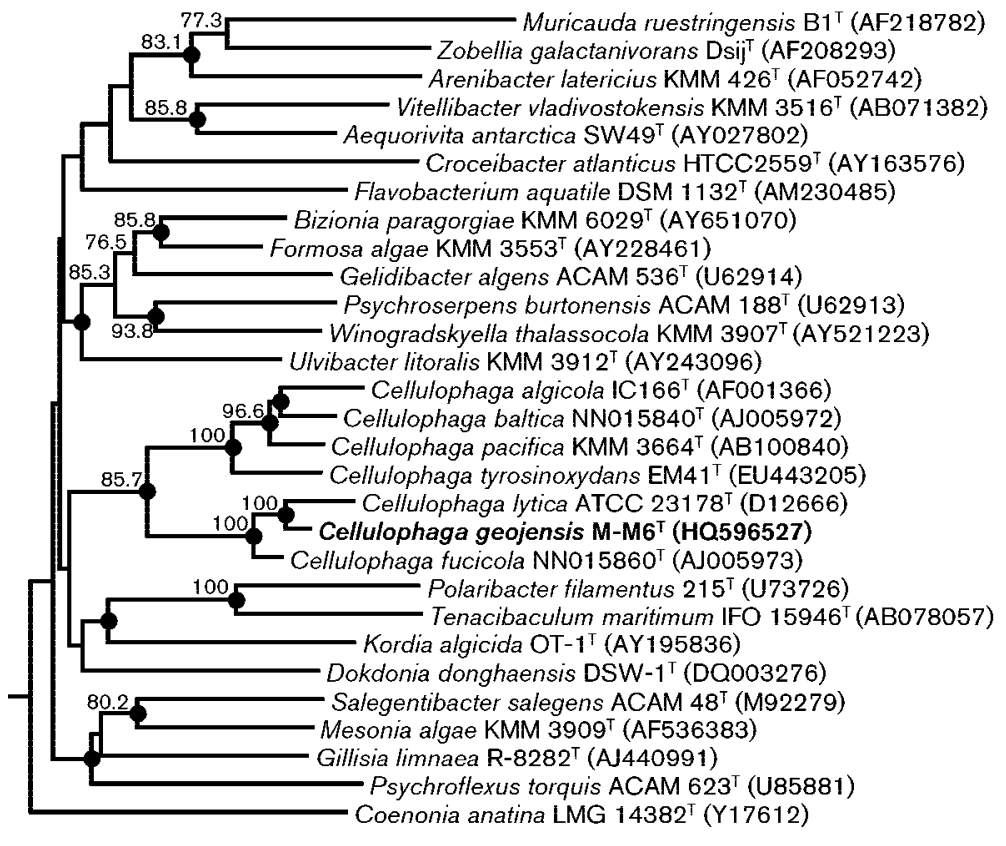

$\underline{0.01}$
Fig. 1. Neighbour-joining phylogenetic tree based on 16S rRNA gene sequences showing the positions of strain $\mathrm{M}-\mathrm{M} 6^{\mathrm{T}}$, the type strains of recognized Cellulophaga species and representatives of some other related taxa. Bootstrap values (expressed as percentages of 1000 replications) of $>70 \%$ are shown at branch points. Filled circles indicate that the corresponding nodes were also recovered in the trees generated with the maximum-likelihood and maximum-parsimony algorithms. Bacteroides fragilis ATCC $25285^{\top}$ (GenBank accession no. X83935) was used as an outgroup (not shown). Bar, 0.01 substitutions per nucleotide position. 
Table 2. Cellular fatty acid compositions (\%) of strain $M-M 6^{\top}$ and the type strains of two phylogenetically related Cellulophaga species

Strains: $1, \mathrm{M}-\mathrm{M6}^{\mathrm{T}}$; 2, C. lytica JCM $8516^{\mathrm{T}} ; 3$, C. fucicola JCM $21778^{\mathrm{T}}$. All data are from this study. Fatty acids that represented $<1.0 \%$ in all strains were omitted. $t r$, Trace $(<0.5 \%)$; - , not detected.

\begin{tabular}{|c|c|c|c|}
\hline Fatty acid & 1 & 2 & 3 \\
\hline \multicolumn{4}{|l|}{ Straight-chain } \\
\hline $\mathrm{C}_{14: 0}$ & 1.2 & 0.6 & 1.5 \\
\hline $\mathrm{C}_{15: 0}$ & 7.4 & 7.4 & 10.2 \\
\hline $\mathrm{C}_{16: 0}$ & 3.2 & 1.0 & $\operatorname{tr}$ \\
\hline \multicolumn{4}{|l|}{ Branched } \\
\hline iso- $\mathrm{C}_{14: 0}$ & 1.1 & 1.2 & 0.8 \\
\hline iso- $\mathrm{C}_{15: 0}$ & 14.9 & 32.0 & 24.3 \\
\hline iso- $\mathrm{C}_{16: 0}$ & 0.9 & 1.1 & $\operatorname{tr}$ \\
\hline iso- $\mathrm{C}_{15: 1} \mathrm{G}^{*}$ & 14.0 & 14.4 & 15.3 \\
\hline anteiso- $\mathrm{C}_{15: 0}$ & 1.5 & 3.8 & 3.3 \\
\hline iso- $\mathrm{C}_{17: 1} \omega 9 c$ & - & 1.8 & - \\
\hline \multicolumn{4}{|l|}{ Unsaturated } \\
\hline $\mathrm{C}_{15: 1} \omega 6 c$ & 1.7 & 1.2 & 3.2 \\
\hline \multicolumn{4}{|l|}{ Hydroxy } \\
\hline $\mathrm{C}_{15: 0} 3-\mathrm{OH}$ & 0.9 & 0.8 & 1.9 \\
\hline $\mathrm{C}_{16: 0} 3-\mathrm{OH}$ & 5.4 & 1.3 & 1.5 \\
\hline iso- $\mathrm{C}_{15: 0} 3-\mathrm{OH}$ & 9.2 & 9.5 & 14.4 \\
\hline iso- $\mathrm{C}_{16: 0} 3-\mathrm{OH}$ & 8.9 & 3.2 & 1.8 \\
\hline iso- $\mathrm{C}_{17: 0} 3-\mathrm{OH}$ & 11.5 & 10.1 & 6.2 \\
\hline \multicolumn{4}{|c|}{ Summed features $\dagger$} \\
\hline 3 & 10.6 & 5.7 & 8.7 \\
\hline 5 & 1.7 & - & - \\
\hline \multicolumn{4}{|c|}{ Unknown fatty acid $\ddagger$} \\
\hline ECL 13.565 & 2.4 & 2.9 & 2.6 \\
\hline
\end{tabular}

${ }^{\star}$ Double bond position indicated by a capital letter is unknown. $\dagger$ Summed features represent groups of two or three fatty acids that could not be separated by GLC with the MIDI system. Summed feature 3 comprised $\mathrm{C}_{16: 1} \omega 7 c$ and/or iso- $\mathrm{C}_{15: 0} \quad 2-\mathrm{OH}$; summed feature 5 comprised $\mathrm{C}_{18: 2} \omega 6,9 c$ and/or anteiso- $\mathrm{C}_{18: 0}$.

\$ECL, Equivalent chain-length.

acid, molybdenum blue, ninhydrin and $\alpha$-naphthol reagents (Minnikin et al., 1984; Komagata \& Suzuki, 1987) and Dragendorff's reagent (Sigma). The polar lipid profiles of strain $\mathrm{M}-\mathrm{M} 6^{\mathrm{T}}$ and the type strains of C. lytica, the type species of the genus, and C. fucicola were almost identical, in that large amounts of two unidentified lipids, one unidentified aminolipid and one unidentified aminophospholipid are present (see Fig. S1 in IJSEM Online). The DNA $\mathrm{G}+\mathrm{C}$ content was determined according to the method of Tamaoka \& Komagata (1984) with the modification that DNA was hydrolysed and the resultant nucleotides were analysed by reversed-phase HPLC [with a YMC ODS-A $(250 \times 4.6 \mathrm{~mm})$ column]. The nucleotides were eluted with a mixture of $0.55 \mathrm{M} \mathrm{NH}_{4} \mathrm{H}_{2} \mathrm{PO}_{4}(\mathrm{pH} 4.0$ ) and acetonitrile $(40: 1, \mathrm{v} / \mathrm{v})$ using a flow rate of $1 \mathrm{ml} \mathrm{min}{ }^{-1}$ at room temperature and were detected by UV absorbance at $270 \mathrm{~nm}$. The DNA G + C content of strain $\mathrm{M}-\mathrm{M}^{\mathrm{T}}{ }^{\mathrm{T}}$ was $35.4 \mathrm{~mol} \%$, a value slightly higher than those reported for members of the genus Cellulophaga (Kahng et al., 2009). Hence, it is reasonable to classify strain $\mathrm{M}-\mathrm{M} 6^{\mathrm{T}}$ as a member of the genus Cellulophaga, as shown by phylogenetic inference and the absence of differential chemotaxonomic properties from recognized Cellulophaga species (Johansen et al., 1999; Bowman, 2000; Nedashkovskaya et al., 2004; Kahng et al., 2009).

DNA-DNA hybridization was performed fluorometrically according to the method of Ezaki et al. (1989) by using photobiotin-labelled DNA probes and microdilution wells. Hybridization was performed with five replications for each sample. The highest and lowest values obtained in each sample were excluded, and the means of the remaining three values are quoted as DNA-DNA relatedness values. Strain $\mathrm{M}-\mathrm{M} 6^{\mathrm{T}}$ exhibited mean levels of DNADNA relatedness of 33 and $35 \%$ to C. lytica JCM $8516^{\mathrm{T}}$ and C. fucicola JCM $21778^{\mathrm{T}}$, respectively. These values indicate that strain $\mathrm{M}-\mathrm{M} 6^{\mathrm{T}}$ represents a genomic species that is distinct from these two Cellulophaga species (Wayne et al., 1987). Strain $\mathrm{M}-\mathrm{M} 6^{\mathrm{T}}$ was clearly distinguishable from C. lytica JCM $8516^{\mathrm{T}}$ and C. fucicola JCM $21778^{\mathrm{T}}$ based on differences in several phenotypic characteristics (Table 1). Phylogenetic and genetic distinctiveness together with differential phenotypic properties are sufficient to allocate strain $\mathrm{M}-\mathrm{M} 6^{\mathrm{T}}$ to a species that is separate from recognized Cellulophaga species (Wayne et al., 1987; Stackebrandt \& Goebel, 1994). Therefore, on the basis of the data presented, strain $\mathrm{M}-\mathrm{M} 6^{\mathrm{T}}$ is considered to represent a novel species of the genus Cellulophaga, for which the name Cellulophaga geojensis sp. nov. is proposed.

\section{Description of Cellulophaga geojensis sp. nov.}

Cellulophaga geojensis (ge.o.jen'sis. N.L. fem. adj. geojensis pertaining to Geoje, the Korean island from where the type strain was isolated).

Cells are Gram-stain-negative, non-spore-forming, nonflagellated and rod-shaped $(0.5-0.8 \mu \mathrm{m}$ in diameter and 2.0-6.0 $\mu \mathrm{m}$ in length). Motile by gliding. Colonies on MA are circular, slightly convex, smooth, glistening, yellow and $1.0-2.0 \mathrm{~mm}$ in diameter after incubation for 3 days at $25{ }^{\circ} \mathrm{C}$. Optimal growth occurs at $25{ }^{\circ} \mathrm{C}$; growth occurs at 4 and $40{ }^{\circ} \mathrm{C}$, but not at $45{ }^{\circ} \mathrm{C}$. Optimal pH for growth is between 7.0 and 8.0; growth occurs weakly at $\mathrm{pH}$ 5.0, but not at $\mathrm{pH}$ 4.5. Optimal growth occurs in the presence of $2 \%(\mathrm{w} / \mathrm{v}) \mathrm{NaCl}$; growth occurs with $0-7.0 \%(\mathrm{w} / \mathrm{v}) \mathrm{NaCl}$. $\mathrm{Mg}^{2+}$ ions are required for growth. Growth does not occur under anaerobic conditions on MA or on MA supplemented with nitrate. Flexirubin-type pigments are not produced. Catalase- and oxidase-positive. Nitrate reduction is negative. Agar, aesculin, casein, carrageenan, CMC, gelatin, starch, L-tyrosine, and Tweens 20, 40, 60 and 80 are hydrolysed, but hypoxanthine, urea and xanthine are not. Cellobiose, D-fructose, D-galactose, D-glucose, maltose, Dmannose, salicin, sucrose, trehalose, D-xylose and Lglutamate are utilized as sole carbon and energy sources, 
but L-arabinose, acetate, benzoate, citrate, formate, Lmalate, pyruvate and succinate are not. Acid is produced from cellobiose, D-galactose, D-glucose, lactose, maltose, Dmannitol, D-mannose, melibiose, sucrose, trehalose and Dxylose, but not from L-arabinose, D-ribose, D-fructose, myo-inositol, melezitose, raffinose, L-rhamnose or Dsorbitol. In assays with the API ZYM and API 20E systems, positive for activities of alkaline phosphatase, esterase (C4), esterase lipase (C8), leucine arylamidase, valine arylamidase, cystine arylamidase, acid phosphatase, naphthol-ASBI-phosphohydrolase, $\beta$-galactosidase and $N$-acetyl- $\beta$ glucosaminidase, but negative for activities of arginine dihydrolase, lysine decarboxylase, ornithine decarboxylase, lipase (C14), trypsin, $\alpha$-chymotrypsin, $\alpha$-galactosidase, $\beta$ glucuronidase, $\alpha$-glucosidase, $\beta$-glucosidase, $\alpha$-mannosidase and $\alpha$-fucosidase. The predominant menaquinone is MK-6. The major fatty acids ( $>10 \%$ of the total) are iso$\mathrm{C}_{15: 0}$, iso- $\mathrm{C}_{15: 1} \mathrm{G}$, iso- $\mathrm{C}_{17: 0} 3-\mathrm{OH}$, and $\mathrm{C}_{16: 1} \omega 7 c$ and/or iso- $\mathrm{C}_{15: 0}$ 2-OH. The major polar lipids are two unidentified lipids, one unidentified aminolipid and one unidentified aminophospholipid. Other phenotypic characteristics are given in Table 1.

The type strain, M-M6 ${ }^{\mathrm{T}}\left(=\right.$ KCTC $\left.23498^{\mathrm{T}}=\mathrm{CCUG} 60801^{\mathrm{T}}\right)$, was isolated from marine sand of Geoje island, Korea. The DNA G + C content of the type strain is $35.4 \mathrm{~mol} \%$ (determined by HPLC).

\section{Acknowledgements}

This work was supported by the 21C Frontier Program of Microbial Genomics and Applications (grant 11-2008-00-002-00) and the Program for Collection, Management and Utilization of Biological Resources (grant M10867010003) from the Ministry of Education, Science and Technology (MEST) of the Republic of Korea.

\section{References}

Baumann, P. \& Baumann, L. (1981). The marine Gram-negative eubacteria: genera Photobacterium, Beneckea, Alteromonas, Pseudomonas, and Alcaligenes. In The Prokaryotes, pp. 1302-1331. Edited by M. P. Starr, H. Stolp, H. G. Trüper, A. Balows \& H. G. Schlegel. Berlin: Springer.

Bernardet, J.-F. \& Nakagawa, Y. (2006). An introduction to the family Flavobacteriaceae. In The Prokaryotes: a Handbook on the Biology of Bacteria, 3rd edn, vol. 7, pp. 455-480. Edited by M. Dworkin, S. Falkow, E. Rosenberg, K.-H. Schleifer \& E. Stackebrandt. New York: Springer.

Bowman, J. P. (2000). Description of Cellulophaga algicola sp. nov., isolated from the surfaces of Antarctic algae, and reclassification of Cytophaga uliginosa (ZoBell and Upham 1944) Reichenbach 1989 as Cellulophaga uliginosa comb. nov. Int J Syst Evol Microbiol 50, 1861-1868.

Bruns, A., Rohde, M. \& Berthe-Corti, L. (2001). Muricauda ruestringensis gen. nov., sp. nov., a facultatively anaerobic, appendaged bacterium from German North Sea intertidal sediment. Int $J$ Syst Evol Microbiol 51, 1997-2006.

Cohen-Bazire, G., Sistrom, W. R. \& Stanier, R. Y. (1957). Kinetic studies of pigment synthesis by nonsulfur purple bacteria. J Cell Comp Physiol 49, 25-68.

Cowan, S. T. \& Steel, K. J. (1965). Manual for the Identification of Medical Bacteria. London: Cambridge University Press.
Ezaki, T., Hashimoto, Y. \& Yabuuchi, E. (1989). Fluorometric deoxyribonucleic acid-deoxyribonucleic acid hybridization in microdilution wells as an alternative to membrane filter hybridization in which radioisotopes are used to determine genetic relatedness among bacterial strains. Int J Syst Bacteriol 39, 224-229.

Johansen, J. E., Nielsen, P. \& Sjøholm, C. (1999). Description of Cellulophaga baltica gen. nov., sp. nov. and Cellulophaga fucicola gen. nov., sp. nov. and reclassification of [Cytophaga] lytica to Cellulophaga lytica gen. nov., comb. nov. Int J Syst Bacteriol 49, 1231-1240.

Kahng, H.-Y., Chung, B. S., Lee, D.-H., Jung, J. S., Park, J. H. \& Jeon, C. O. (2009). Cellulophaga tyrosinoxydans sp. nov., a tyrosinase-producing bacterium isolated from seawater. Int J Syst Evol Microbiol 59, 654-657.

Komagata, K. \& Suzuki, K. (1987). Lipid and cell wall analysis in bacterial systematics. Methods Microbiol 19, 161-207.

Lányí, B. (1987). Classical and rapid identification methods for medically important bacteria. Methods Microbiol 19, 1-67.

Leifson, E. (1963). Determination of carbohydrate metabolism of marine bacteria. J Bacteriol 85, 1183-1184.

Lewin, R. A. (1969). A classification of flexibacteria. J Gen Microbiol 58, 189-206.

Minnikin, D. E., O’Donnell, A. G., Goodfellow, M., Alderson, G., Athalye, M., Schaal, A. \& Parlett, J. H. (1984). An integrated procedure for the extraction of bacterial isoprenoid quinones and polar lipids. J Microbiol Methods 2, 233-241.

Nedashkovskaya, O. I., Suzuki, M., Lysenko, A. M., Snauwaert, C., Vancanneyt, M., Swings, J., Vysotskii, M. V. \& Mikhailov, V. V. (2004). Cellulophaga pacifica sp. nov. Int J Syst Evol Microbiol 54, 609-613.

Reichenbach, H. (1989). Genus I. Cytophaga Winogradsky 1929, $557^{\mathrm{AL}}$ emend. In Bergey's Manual of Systematic Bacteriology, vol. 3, pp. 2015-2050. Edited by J. T. Staley, M. P. Bryant, N. Pfennig \& J. G. Holt. Baltimore: Williams \& Wilkins.

Reichenbach, H. (1992). The order Cytophagales. In The Prokaryotes. A Handbook on the Biology of Bacteria: Ecophysiology, Isolation, Identification, Applications, 2nd edn, vol. 4, pp. 3631-3675. Edited by A. Balows, H. G. Trüper, M. Dworkin, W. Harder \& K. H. Schleifer. New York: Springer.

Sasser, M. (1990). Identification of bacteria by gas chromatography of cellular fatty acids, MIDI Technical Note 101. Newark, DE: MIDI Inc.

Stackebrandt, E. \& Goebel, B. M. (1994). Taxonomic note: a place for DNA-DNA reassociation and $16 \mathrm{~S}$ rRNA sequence analysis in the present species definition in bacteriology. Int J Syst Bacteriol 44, 846-849.

Staley, J. T. (1968). Prosthecomicrobium and Ancalomicrobium: new prosthecate freshwater bacteria. J Bacteriol 95, 1921-1942.

Tamaoka, J. \& Komagata, K. (1984). Determination of DNA base composition by reverse-phase high-performance liquid chromatography. FEMS Microbiol Lett 25, 125-128.

Wayne, L. G., Brenner, D. J., Colwell, R. R., Grimont, P. A. D., Kandler, O., Krichevsky, M. I., Moore, L. H., Moore, W. E. C., Murray, R. G. E. \& other authors (1987). International Committee on Systematic Bacteriology. Report of the ad hoc committee on reconciliation of approaches to bacterial systematics. Int J Syst Bacteriol 37, 463-464.

Yoon, J.-H., Kim, H., Kim, S.-B., Kim, H.-J., Kim, W. Y., Lee, S. T., Goodfellow, M. \& Park, Y.-H. (1996). Identification of Saccharomonospora strains by the use of genomic DNA fragments and rRNA gene probes. Int J Syst Bacteriol 46, 502-505.

Yoon, J.-H., Lee, S. T. \& Park, Y.-H. (1998). Inter- and intraspecific phylogenetic analysis of the genus Nocardioides and related taxa based on 16S rDNA sequences. Int J Syst Bacteriol 48, 187-194.

Yoon, J.-H., Kim, I.-G., Shin, D.-Y., Kang, K. H. \& Park, Y.-H. (2003). Microbulbifer salipaludis sp. nov., a moderate halophile isolated from a Korean salt marsh. Int J Syst Evol Microbiol 53, 53-57. 